\title{
Notes
}

\section{Equalization of Municipal Services: The Economics of Serrano and Shaw}

In recent years, a number of courts have used the Equal Protection Clause to mandate substantial changes in the distribution of local public goods and services. Their decisions form two distinct groups. In the first, including Hobson v. Hansen, ${ }^{1}$ Hadnot v. Cily of Praltville, ${ }^{2}$ and Hawkins v. Town of Shaw, ${ }^{3}$ the courts ordered equalization of municipal services between racially distinct neighborhoods where existing distribution patterns were characterized by considerable disparities. ${ }^{4}$ In the second, including Serrano v. Priest ${ }^{5}$ and its progeny, ${ }^{\circ}$ the courts invalidated state systems of educational finance which made the quality of a child's education dependent on the wealth of his family and his community. These cases have been paralleled by a vast and rapidly expanding collection of legal commentary advocating judicial action to introduce greater equality in the distribution of public goods and services. ${ }^{8}$ Yet, while both the cases and commentary have explored the

1. Hobson v. Hansen, 269 F. Supp. 401 (D.D.C. 1967), aff'd sub nom. Smuck v. Hob. son, 408 F.2d 175 (D.C. Cir. 1969).

2. Hadnot v. City of Prattville, 309 F. Supp. 967 (D. Ala. 1970).

3. Hawkins v. Town of Shaw, 437 F.2d 1286 (1971), affd cn banc, 401 F.2d 1171 (jth Cir. 1972).

4. While it did not deal with traditional municipal services, Norwalk CORE v. Norwalk Redevelopment Agency, 395 F.2d 920 (2d Cir. 1968), involicd a similar problem of equalization within the local public sector: Low income blacks and low income whites were not being relocated with equal effectiveness following urban renewal.

5. Serrano v. Priest, 5 Cal. 3d 584, 487 P.2d 1241, 96 Cal. Rptr. 601 (1971).

6. San Antonio Independent School Dist. v. Rodriguez, 337 F. Supp. 280 (W.D. Tex. 1971), prob. juris. noted, 92 S. Ct. 2413 (1972); Van Dusartz v. Hatficld, 334 F. Supp. 870 (D. Minn. 197I); Hollins v. Shofstall, No. C-253652 (Super. Ct. Ariz. Jan. 13, 1972): Robinson v. Cahill, 118 N.J. Super. 223, 287 A.2d 187 (1972). Similar suits are at various stages of the judicial process in at least twenty-six additional statcs. INAt.rsis of INTRAstate School Finaxce Cases, U.S. Office of Education Task Force on School Finance (1972).

7. Prior to Serrano, at least two federal courts had refused to order statewide equal. ization of educational opportunities on the basis of student necds. Burruss v. Wilkerson, 310 F. Supp. 572 (W.D. Va. 1969), affd mem., 397 U.S. 44 (1970); Miclnnis v. Shapiro, 293 F. Supp. 327 (N.D. Ill. 1968), aff'd per curiam sub nom. MIcInnis v. Ogilvic, 394 U'S. 322 (1969). These earlier cases were distinguished in Serrano et al. on grounds that questions of student need were substantially different from questions of school finance. 5 Cal. 3d at 615-17, 487 P.2d at 1263-65, 96 Cal. Rptr. at 623.25. The only case following McInnis is Spano v. Board of Education of Lakeland Cent. School Dist. \#1, 68 Misc. $2 d$ 804, 328 N.Y.S.2d 229 (Sup. Ct. 1972).

8. The number of articles in the field is legion. See note 11 infra for a summary of views presented in the commentary and references to illustrative sources. 
relevant doctrinal issues at length, ${ }^{0}$ they have devoted surprisingly little attention to the economic consequences of, or grounds for, judicial intervention. ${ }^{10}$

This Note will analyze the probable impact of judicial intervention in terms of a plausible and relatively familiar economic model for the efficient provision of local public goods and services. Part I describes the model within the framework of traditional economic analysis; Part II then explores the consequences that result when various assumptions underlying the model are relaxed. In both sections, the implications of a judicially-imposed standard of per capita equality are examined. This particular standard was chosen because it is frequently, although not uniformly, suggested by both the courts ${ }^{11}$ and commen-

9. See, e.g., J. Coons, W. Clune, \& S. Sugarman, Private Wealti and public liduga. TION (1970); Goldstein, Interdistrict Inequalities in School Financing: $A$ Critical Analysis of Serrano v. Priest and Its Progeny, 120 U. PA. L. Rev. 720 (1972); Michelinan, Forward: On Protecting the Poor Through The Fourteenth Amendmenl, 83 HARv. L. Rev. 7 (1969): Ratner, Inter-Neighborhood Denials of Equal Protection in the Provision of Municipal Services, 4 Harv. Civ. Rights-Civ. Lib. L. REv. 1 (1968); Comment, The Evolution of Eyual Protection: Education, Municipal Services, and Wealth, 7 HARv. Civ. Ricirts.Civ. Liw. L. REv. 103 (1972).

10. There are several notable exceptions. Coons, Clune \& Sugarman, supra note 9, explore in some detail the fiscal effects of financing public education through property taxes levied and spent by autonomous local political units. Schocttle, The Egual Pro. tection Clause in Public Education, 71 Colum. L. REv. 1355 (1971), analyzes the in. plications of local governmental budgetary decision-making processes for judicial intervention in the financing of public education. Note, $A$ Statistical Analysis of the School Financing Decisions: On Winning Battles and Losing Wars, 81 YALE L.J. 1903 (1972), examines the potential impact of a centralized cdicational financing system on the tax burdens of those in various income groups and communities within Connecticut.

11. The courts in Hobson, Norwalk CORE, Hadnot, and Shaw explicitly imposed standards of per capita equality between racially segregated sections of single political units. In Hadnot the court "permanently enjoined and restrained [the defendants] from failing to substantially equalize, within one year from the date of [the] orcler, the equipment, facilities, and services provided in North Highland Park [situated in the black section of town] with those heretofore provided in and for Pratt Park [situated in the white section of town]." $309 \mathrm{~F}$. Supp. at 975 (emphasis added). In Shaw" the de. fendants were ordered to prepare a plan, subject to court approval, for "the ecfualiza. tion of municipal services" between black and white arcas of the town. 497 F.2d at 1293. In Hobson the court required equalized distribution of teachers among all schools in the District of Columbia, as measured by salary expenditures. While not specifically requiring equalization of per pupil expenditures for black and white studcuts, the court implicitly adopted that standard as the appropriate criterion against which to test the distribution of educational services. Finally, the decision in Norwalk CORL, although not involving a final decree, suggested that the only appropriate remedy would be equally effective relocation for both whites and non-whites. $395 \mathrm{~F} .2 \mathrm{~d}$ at 929.80 .

These decisions may be viewed as traditional Fourteenth Amendment catses involving racial discrimination. But they can also be interpreted as setting an implicit standard of per capita equality within political units in the face of disparities by race or ill. come. See, in particular, the first majority opinion in Shaw, $437 \mathrm{~F} .2 \mathrm{~d}$ at $1287 \mathrm{n.1}$, and the subsequent concurring opinion by Judge Wisdom in the en banc decision, 461 F.2 at 1175 . For a contrary view, sec Judge Roney's dissent in the en banc decision, 161 F.2d at 1182-83. Both interpretations involve certain difficulties, as discussed at pp. 105.06,
113.15 infra.

The school finance cases have thus far expressly declined to specify a particular mode of cducational funding. There is language in Serrano which strongly implies that cdic. cational expenditures must be equivalent for all students. See 5 Cal. $3 \mathrm{~d}$ at $604.10,487$ P.2d at 1255-59, 96 Cal. Rptr. 615-19. Yet there is also a strong suggestion in the 
tators, ${ }^{12}$ and because it is an effective means of highlighting the economic model itself. The central thesis of that model is that allocative efficiency results from the differential availability of municipal services

opinion that the court would go no further than to require a system of "fiscal capacity equalizing" or "fiscal neutrality," whereby a given tax rate would permit the same level of expenditure per pupil in any community. See id. at 597.604, 487 P.2d at 1250-55, 96 Cal. Rptr. at 610-15. Post-Serrano decisions have been almost as vague in defining appropriate remedies. The Rodriguez court emphasized that it was requiring only "fiscal neutrality" and was not establishing a standard of per capita equality in educational expenditures. Nevertheless, while leaving the legislature with responsibility for formulating a specific financing system, the court did indicate that state-wide uniformity would be one acceptable approach. See 337 F. Supp. at 283.84. In contrast, there is language in Robinson implying that both a state gtarantec of some adequate minimum educational output and the equalization of fiscal capacities would be required. See 287 A.2d at 217.

12. Prior to Shaw several commentators urged judicial imposition of a standard of per capita equality in the provision of municipal services. See, e.g., Abascal, Municipal Services and Equal Protection: F'ariations on a Theme by Griffin v. Illinois, 20 Hist. L.J. 1367 (1969); Ratner, supra note 9, at 40; Note, The Right to Adequate Municipal Services: Thoughts and Proposals, 41 N.Y.U.L. REv. 753 (1969). See also F. Michelman. Obtaining a Fair Share of Municipal Services Through Lcgal Procecdings (undated memo prepared for the Civil Rights Law Institutes of the N.ACP Legal Defense and Educational Fund).

Since Shaw, the standard of per capita equality within political units has been accepted without question by the commentators. See, e.g., Comment, Equal Protection: The Right to Equal Municipal Services, 37 BrookLYN L. REv. 503 (1971); Note, Constilutional Law-Equal Protection-Affirmative Relief Requiring Equalization of Municipal ServicesHawkins v. Town of Shaw, $49 \mathrm{~J}$. URB. L. 425, 436-37 (1971); Note, Equal Protection in the Urban Environment: The Right to Equal Afunicipal Services, 40 TUL. L. REv. 495 (1972). See also Ellington and Jones, The Court as City Manager, 5 GA. L. REv. 734 (1971); Comment, Hawkins v. Town of Shaw-Equal Protection and Mfunicipal Services: A Small Leap for Minorities but a Giant Leap for the Commentators, 1971 UTAll L. REv. 397.

Among numerous pre-Serrano works advocating state-wide equalization of public school expenditures and/or educational opportunity: A. W'ise, Ricu Scilools, Poon Schools: The Promise of Equal Educational Opportunitr (1968); Horowitz \& Ncitring, Equal Protection Aspects of Inequalities in Public Education and Public Assistance Pro. grams from Place to Place Within a State, 15 U.C.L.A L. REv. 787 (1968); Rousellot, Achieving Equal Educational Opportunity for Negroes in the Public Schools of the North and West: The Emerging Role for Private Constitutional Litigation, 35 GEo. WASII. L. REv. 698 (1967); Comment, Constitutional Law: Financing Public Education Under the Equal Protection Clause, 23 U. FLA. L. REv. 590 (1971); Comment, Intrastote Inequalities in Educational Opportunity, 1970 Wis. L. Rev. 7 (1970). But see Coons, Clune, and Sugarman, supra note 9 (rejecting direct equalization and arguing instead for a system of fiscal capacity equalizing); Mfichelman, supra note 9 (arguing for a "minimum protection" standard).

One of the few post-Serrano pieces to focus on the question of standards is Note, Equal Educational Opportunity: A Case for the Children, 46 Sr. Jous's L. REv. 280 (1971). It rejects both fiscal equalization and minimum standard guarantees in favor of per capita equality. The Symposium, W'ho Pays for Tomorrow's Schools: The Emerging Issues of School Finance Equalization, 2 YALE REv. L. AND Soc. Acrion I (1972), contains, inter alia, critiques of Serrano by Wise and by Coons, Clune \& Sugarman. The former urges that Serrano be interpreted as mandating per capita equality, id. at 127-30; the latter, that Serrano be interpreted as mandating fiscal capacity cqualization, id. at 117-19. See also the pre-Serrano works by these commentators, supra notes $9 \mathrm{\&} 12$. C . Ridenour \& Ridenour, Serrano $v$. Priest and the Financing of Public Education in Kansas: Beyond the Rhetoric, 20 KAN. L. REv. 433 (1972); Note, A Statistical Analysis of the School Finance Decisions: On Winning Ballles and Losing W'ars, 81 YaLE L.J. 1303 (1972).

Finally, it has been suggested that Shaw and Serrano may be read together to re. quire state-wide equalization of all municipal scrvices. Sec, e.g., Comment, The Eurolu. tion of Equal Protection, supra note 9, at 199. 
coupled with individual choices of residential location; a standard of per capita equality would clearly destroy this efficiency generating process.

Part III explores redistribution as a justification for altering the consequences described by the economic model. This issue is first discussed in terms of a theory of fundamental interests whereby all individuals are deemed to have a basic right to specific goods or services. It is suggested that such a right, as well as the distribution pattern that appropriately accompanies it, must hinge on the nature of the specific good or service in question, rather than on the process by which the good or service is distributed. In this regard, a standard of per capita equality may well have substantial conceptual and practical flaws, and it further appears that any standard that confines its focus to particular distribution processes may be equally unsound.

Part III also discusses the redistribution issue in connection with the methods by which municipal services are financed. Residence in a wealthy community provides substantial advantages which are denied low income persons by exclusionary zoning. This, in turn, is simply one aspect of a range of distributional questions relating to locational opportunities. In this context, equalization of fiscal capacities and the elimination of exclusionary zoning are explored as potential judicial standards. Here it appears that, while both have uncertain consequences from an efficiency standpoint, the elimination of exclusionary zoning is the most appropriate means of influencing the distribution of income, while equalization of fiscal capacities represents, at best, an uneasy compromise.

\section{The Theoretical Models}

Neoclassical economics, which provides the conceptual framework for the following discussion, is concerned with the efficient allocation of resources and of goods and services. Efficiency in consumption is viewed in terms of the traditional Pareto optimal condition that no individual can be made better off without making some other person worse off. Conversely, if a system fails to exploit situations where the welfare of some individuals could be increased without reducing the welfare of others, then it is an inefficient system of allocation. ${ }^{13}$

13. The allocation of resources for the production of goods and scrvices and the allocation of goods and services among consumers are a single process. The discussion here, however, focuses only on the latter part of the process.

The distinction between allocation and distribution must be kept clear. 'The former 
The process whereby efficiency is achieved depends on various characteristics of the good or service involved. Economics has traditionally dealt with two polar categories: pure private and pure public goods. Only recently has attention shifted to the hybrid category of "local" public goods and services.

\section{A. The Allocation of "Pure" Goods and Services"}

The basic teaching of traditional economic theory is that under certain conditions ${ }^{15}$ efficiency will result from market (private sector) allocation. One of these conditions is that the goods and services be purely private-that their benefits accrue solely to the individual consumer, and that it is feasible to exclude others from enjoying them. The model also assumes a given pattern of income distribution. ${ }^{10}$ The most remarkable aspect of the private sector is, of course, that it functions properly when each individual acts independently to maximize his own welfare. That is, the marketplace "automatically" operates efficiently; it is unnecessary to introduce collective regulation or decision-making.

There are, however, certain types of goods and services which the marketplace cannot allocate efficiently. ${ }^{17}$ This is particularly true of pure public goods and services-rwhere the utility ${ }^{18}$ derived by one individual does not reduce the benefits available to all other individ-

refers to the goods and services obtained by individuals given their incomes and wealth; the latter refers to transfers between individuals which are not in exchange for goods or services. These transfers may be in the form of cither ash (income) or goods and services (in-kind).

14. Among numerous works on private sector allocation, sec, e.g., W. B.tustot, Economic Theory and Operations ANalysis (2d ed. 196j); R. Dorfuas, TIE Prace SYSTEM (1964); C. Ferguson, Mfreroeconomic Theory (rev. ed. 1909); J. HeNdensoN \& R. Quand, Microeconomic Theory: A Minthematical Aproacil (2d ed. 197i).

Discussion of public finance theory throughout this Note relics in large measure on J. Buchanax, The Deacand and Supply of Punlac Goons (1968); W. Hinsci, TuE Economics of State aNd Local Government (1970); L. Jollansen, Public Economics (1965); R. Musgrave, The Theory of Public Finasce (1959); C. Shoup, Public Finasce (1969).

15. These conditions include the following: the goods and serviecs produced and distributed are purely private, competition is pure, all participants possess perfect knowledge, individuals act in their own self-interest, the economy is at full-cmplojment, and the society has realized its desired pattern of income distribution.

16. If the society chooses to alter the distribution pattern, then the optimal allocation pattern will also change. See pp. 108-11 infra.

It should be noted that distribution is concerned with wealth as well as with income. These two terms are used interchangeably throughout.

17. In general, there are three bases for government intervention in the production and provision of goods and services: allocation, redistribution, and stabilization. The first involves public goods and services, as discussed below. It also involves regulation in situations of "natural monopoly" and efforts to maintain purely competitive conditions in the private sector. Stabilization involves efforts by the government to influcnec rates of growth, emplojment, and inflation. The redistributive function is discussed in l'art III infra. See, e.g., R. MusGrave, supra note 14 , at $\mathbf{7 - 9}$.

18. "Utility" refers to the individual's valuation of the benefits of a good or senice. 
uals, ${ }^{10}$ and there are no significant technological constraints on the geographic area or number of persons benefited. ${ }^{20}$

Given these characteristics, it is not feasible to reach optimal allocation through the private market. Each inclividual will have little incentive to purchase his own public goods and services but rather will rely on others to acquire amounts which will necessarily accrue to his own benefit. Thus, while the "invisible hand" of the market automatically leads to efficient allocation of private goods and services, the allocation of public goods and services requires some political process whereby individuals can be induced to reveal their true preferences and compelled to contribute to public revenues accordingly. ${ }^{21}$ Despite numerous attempts to develop methods for realizing this norm,22 substantial practical difficulties leave the public sector model largely where it began-a "purely" conceptual solution.

In addition to this distinction between purely private and purely public allocational processes, there are also substantial differences in outcome. In the private sector, individuals can consume different amounts of goods and services but must pay the same price for consuming the same amount. These different consumption levels reflect two factors: differences in individual preferences for various goods and services, ${ }^{23}$ and differences in aggregate income. While in the public

19. "Benefits" refers to the objective attributes of the good or scrvice itsclf. Thus, all individuals receive identical benefits from a given amount of a good or service, while different individuals may derive different utility from that given amount.

20. The classic example of a pure public good is national defense. The utility that a given individual derives from a given level of military preparedness does not reduce the benefits available to all others; it is impossible to exclude specific persons from such protection; there are no technological constraints on geographic benefit arcil (only political choices as to national boundaries); and the benefits available to each individual do not decrease as the number of persons within the nation increases.

21. Difficulties in defining methods for financing and producing "correct" announts of pure public goods and services have long preoccupied economists. Musgrave's classic work, THE THEORY of PUBLic Finance, provides a comprehensive historical summary in the context of modern economic analysis, along with copious bibliographical matcrial. R. MUSGRAVE, supra note 14, at 61-201.

Using concepts developed in traditional microcconomic theory, a solution to the ques. tion of proper financing and production levels was first given its modern formulation by Samuelson in The Pure Theory of Public Expenditures, 36 REv. ECon. \& STA'r. 887 (1954). See also Samuelson, Diagrammatic Exposition of a Pure Theory of Public Expenditures, 37 REV. ECON. \&: STAT. 350 (1955).

22. See, e.g., K. Arrow, Social Chotce and Individual Values (2d ed. 1968); J. Bu chanan \& G. Tullock, The Calculus of Consent: Locical foundations of Constitu. tional Democracy (1962); R. Dahl \& C. Lindblom, Politics, Economics and Welfare (1953); A. Downs, Inside Bureaucracy (1967). Illustrative articles on this subject arc Birdsall, $A$ Study of the Demand for Public Goods, in Ess,IYs in FisGal Fedekalism 235 (R. Musgrave ed. 1965); Clarke, Multipart Pricing of Public Goods, 11 Pun. Cuotce 17 (1971); Davis and Haines, A Political Approach to a Theory of Public Expenditure: The Case of Municipalities, 19 NaT'L TAx J. 259 (1966); Demsetz, The Exchange and En. forcement of Properly Rights, $7 \mathrm{~J}$. LAw \& Econ. 11 (1964).

23. One private sector equilibrium condition is that for a given individual the marginal utility is the same for the last unit of each good and service consumed. If 
sector all individuals must consume the same amount of a pure public good or service, they may nevertheless contribute different amounts toward its cost. This latter feature results from the fact that-at least in theory ${ }^{24}$-each individual contributes to the cost of the pure public good or service that portion of his income which he would be willing to spend $^{25}$ on the amount of the good or service he receives, having been "forced" by appropriate political processes to reveal his true preferences. These different payments thus reflect different preferences, while the availability of equivalent benefits stems from the nature of the goods and services themselves. Consequently, the fact that some individuals pay more than others for the same amount of public goods and services need not represent an in-kind redistribution of income.".

\section{B. Allocation of Local Public Goods and Services}

While these concepts are convenient for analytical purposes, it is apparent that very few public goods and services are "pure." Although the services provided by local government exhibit some of the collective characteristics attributed to pure public services, ${ }^{27}$ none is

this is not the case, the individual will cxchange the last unit of the good from which he derives lower marginal utility for more of the good with higher marginal utility. However, the consumption mix that meets this condition may differ from consumer to consumer.

24. See p. 94 supra. Moreover, tax law, as it has developed, requires a standard of "equal treatment of equals" in terms of the relevant tax base, but not in terms of "marginal utilities." See note 23 supra. Nevertheless, a system of proportional taxation can be viewed as embodying the notion that the preference for each public good and service relative to the consumption of all others is a constant; a system of progressive taxation can be viewed as embodying the notion that that preference ratio inereases as income increases. But see W. BLUM \& H. Kalves, THE Uneasy Case for Progressive TAxation (1953).

25. The condition that each individual contribute his marginal valuation of the last unit of each service received times the total quantity received is sufficient to yield a Pareto optimal solution. This standard was first suggested by Erik Lindahl in DiE GERECHTIGKEIT DER BESTEUERUNG (Lund 1919), as translated and reprinted as Just Taxation-A Positive Solution, in Chassics in the Theory of Public Finavee 168 (Musgrave \& Peacock eds. 1958). This is not, however, a necessary condition. is shown by Johansen, Some Notes on the Lindahl Theory of Determination of Public Expendi. tures, 4 INT'L EcoN. Rev. 346 (1963), a Pareto optimal solution will exist for any scheme of taxation. Consequently, an optimal allocation of public goods and services does not require a particular financing scheme. Nevertheless, to the extent that the tax structure deviates from the standard suggested by Lindahl, some redistribution of income will take place. This latter, of course, may be consistent with the redistributive objectives of the society or may be offset by other redistributive programs.

26. Redistributive questions are treated in Part III infra.

27. For example, an educated populace is vital to a properly functioning democracy, since it fosters enlightened political participation and opportunities for individual economic mobility; it also contributes substantially to aggregate cconomic growth. Each individual has access to these benefits and cannot be excluded from enjoying them. The benefits of crime and fire prevention, and reduced risk of personal injury and property loss, accrue to all persons within service areas. Similarly, collective benefits are derived from a healthy and sanitary community, since each individual's risk of illness is reduced if his neighbors remain healthy. For a discussion of these as well as other municipal services, see, e.g., C. Shoup, supra note 14, at 101-44. 
purely public: Collective benefits accrue to limited geographic areas, ${ }^{28}$ and certain local public services possess "private" characteristics enjoyed independently by each individual. ${ }^{20}$ Consequently, the provision of local public goods and services is often characterized by geographic and individual inequalities. ${ }^{30}$

In his classic article, "A Pure Theory of Local Expenditures," Charles Tiebout demonstrated that precisely this discriminatory (exclusionary) potential facilitates a market solution to the allocation of such goods and services, despite their public attributes. While his model only crudely approximates "real world" processes, the Tiebout Hypothesis has been widely accepted as a starting point for much of local public finance theory. With slight modifications, ${ }^{32}$ it provides the basis for the ensuing analysis.

The model is founded on three key assumptions: ${ }^{33}$ complete residential mobility, no cost or benefit spillovers between communities, and no employment considerations which affect locational choice. ${ }^{34}$ Moreover, income distribution is regarded as a non-issue. ${ }^{35}$

Given these assumptions (and one other relating to economies of scale), ${ }^{36}$ the model postulates that allocative responsibility is given to

28. As is apparent, the goods and services mentioned at note 27 supra do not neces. sarily benefit wide geographic areas.

29. The public attributes of local public goods and services are reinforced by the system of "free" provision. Thus, certain goods and services readily allocated by the private sector are nevertheless provided by the public sector on grounds that all persons are better off if each person has access to them.

Given the substantial private benefits inherent in municipal services, this system of "free" provision is not essential. It may operate alongside, or be replaced by, a sys. tem of private allocation. Thus, private schools, private recreational or cultural facilities, and private health services are commonplace.

30. See C. Shoup, supra note 14, at 101-44.

31. Tiebout, $A$ Pure Theory of Local Expenditures, 64 J. Pol. Econ. 416 (1956). Ticbout refined his model in An Economic Theory of Fiscal Decentralization, in Puulic Finances: Needs, Sources, and Utilization 79 (National Bureau of Economic Rescarch ed. 1961).

32. See note 36 infra.

33. In his original article, Tiebout relied on seven assumptions: full mobility and willingness to move, full knowledge of choices, a large number of communities to choose from, no restrictions due to employment considerations, no spillovers of costs or bencfits, a technologically determined optimal community size for each service, and at. tempts to realize that size. Tiebout, $A$ Pure Theory of Local Expenditures, supra notc 31 , at 419 .

34. This assumption raises two sets of questions. First, employment considerations may confine the feasible range of choices open to an individual to a given community or metropolitan area. As such, they represent an additional barricr to mobility. Sct pp. 103-04 infra. On the other hand, a recent critique of the Tiebout Hypothesis has suggested that private sector employment considerations may cause the results generated under the Tiebout process, even in its purest form, to be incfficient. Buchanan and Goetz, Efficiency Limits of Fiscal Mobility: An Assessment of the Tiebout Model, $1 \mathrm{~J}$. Pub. Econ. 25 (1972). See pp. 106.08 infra.

35. See Part III infra for discussion of this issuc.

36. As indicated at note 33 supra, Tiebout assumes that there is a technologically determined optimal community size for each type of service, and that each community seeks to realize that size. In the present context, however, it is convenient to disregard 
political units ${ }^{37}$ whose boundaries coincide with the benefit area for the good or service provided, a "benefit area" being that region in which the good or service is purely public. ${ }^{38}$ Consequently, all individuals within a single political unit will have access to the same level of benefits; all those outside the unit will receive no benefits whatsoever. ${ }^{30}$ The various political units will provide and charge fort ${ }^{40}$ differing amounts of the good or service. In a process analogous to "shopping in the marketplace," 41 each individual, presented with a range of choices as to prices and quantities, will locate so as to maximize his utility with respect to the consumption of local public goods and services. ${ }^{2}$ Thus, the individual reveals his preferences through his locational decision. ${ }^{43}$ The result will approach optimal allocation of resources as the number and variety of alternative communities increases.

While there will be no per capita inequalities within political units, inequalities among units are fundamental.:4 Given these inequalities, each individual can and must choose his level of consumption and expenditure by residing where he obtains his preferred mix of municipal services. In effect, judicially-imposed per capita equality removes this choice, ${ }^{4 \overline{5}}$ thereby imposing substantial allocative inefficiencies. In

scale considerations temporarily, and to assume that size is determined by the benefit area for the specific local public good or service distributed by the particular political unit. Under this assumption, there can be no incqualities within political units. This permits a clear-cut exposition of the impact of a standard of per capita equality as applied to independent political units. The possibility of intra-unit inequalities is treated at pp. 98-103 infra.

37. Any political body which has the authority to levy taxes and distribute goods or services may be considered a political unit, including special purpose units such as school districts. Special assessment districts may also be vievied as political units. See note 61 infra.

38. But see notes 28-29 supra.

39. These features are seldom found in reality. See pp. 100-03 infra for discussion of deviations from the assumption of a one-to-one relationship between political unit and benefit area boundaries.

40. Tiebout never expressly addressed the issue of how local public goods and serviecs should be financed. By analogy to the private sector, ench individual should pay the same flat-rate user charge per unit of good or service received. Yet such goods and services are public within benefit areas and arguably should be financed accordingly. As suggested at note 25 supra, the method of financing within benefic areas is not tied directly to the question of optimal allocation. Hovever, the method of financing will have a substantial bearing on a variety of distributional issues. See pp. 115.2I infra.

The method by which local public goods and services are financed may also influence the efficiency properties of the Tiebout process itsclf and will have a marked impact on individual incentives. See pp. 106-08, $113-15$ infra.

41. Tiebout, A Pure Theory of Local Expenditures, supra note 31, at 422.

42. Hereinafter generally referred to simply as "municipal services."

43. See p. 94 supra.

44. Under the Tiebout Hypothesis, inequalities would not arise if all individuals chose to purchase the same quantity of any given local public good or service.

45. In McInnis, this factor provided a justification for the court's refusal to interfere with the Illinois system of financing public education. "[L]ocal citizens must select which municipal services they value most highly. While some communities might place 
the absence of income transfers, ${ }^{46}$ a standard of per capita equality simply requires some units to purchase more, and some less, of each municipal service. While the resulting uniform levels may meet the desires of some individuals, most people will be forced to accept a nonoptimal consumption mix.

\section{Deviations from the Model}

If the Tiebout Hypothesis perfectly mirrored reality, judicial intervention would be manifestly unwarranted, at least on allocative grounds. ${ }^{47}$ However, as with other theoretical constructs, the assumptions underlying the model do not fully portray actual conditions. These deviations must be explored in assessing the validity of implications drawn from the model.

\section{A. Variations in Political Boundaries}

The model assumes a one-to-one relationship between political unit and benefit area boundaries. ${ }^{48}$ In other words, it assumes that every individual within a political unit has access to the same level of municipal services, and that none of their benefits accrue to those outside the political unit.

In practice, this one-to-one relationship is seldom realized. A single political unit is likely to provide some municipal services for multiple benefit areas, while a single benefit area for other services is likely to encompass more than one political unit. Thus, it is necessary to ex-

heavy emphasis on schools, others may cherish police protection or improved roads." 293 F. Supp. at 333.

In Serrano, the court expressly declined to reach the question of whether independent choice of consumption patterns would be appropriate. "We need not decide whether such decentralized financial decision-making is a compelling state interest, since under the present financing system such fiscal free-will is a cruel illusion for the poor school districts." 5 Cal. 3d at 611,487 P.2d at 1260, 96 Cal. Rptr. at 620. This passage in. plics that, given sufficient financial aid to poorer districts, prestmably in the form of fiscal capacity equalization, see pp. 115-21 infra, independent choice would be acceptable. It is not clear why the court refused simply to statc this proposition, particularly in light of its reliance on the work of Coons, Clune and Sugarman, supra note 9. Part of the reason may lie in its treatment of education as a fundamchtal interest. In the context of the court's doctrinal concern over the unique and funda. mental character of education, a system permitting deviation from a stanclard of state-wide equality might appear to violate the Equal protection Clausc. The court in Rodriguez, untroubled by this anomaly, expressly allowed (although it did not requirc) some form of fiscal capacity equalization. 337 F. Supp. at 284. These issues are dis. cussed at pp. 109-11 infra.

46. See Part III infra.

47. Alternative grounds are discussed in Part III infra. In addition, introduction of private sector locational considerations may cause inefficiencies. See pp. 106.08 infra.

48. See pp. 96.97 supra. 
amine the efficiency implications of such deviations, and determine whether they justify imposition of a standard of per capita equality.

\section{Spillovers}

Benefit spillovers occur where the benefit area for a public good or service extends beyond the boundaries of the local political unit responsible for its distribution. This commonly results when nonresidents enter the political unit and make use of the goods and services it provides. ${ }^{49}$ Spillovers may also result from the nature of the good or service itself,50 or from the emigration of recipients of educationrelated services. ${ }^{51}$ These benefit spillovers are paralleled by cost spillovers. For example, local taxes may be passed on to non-resident users. ${ }^{52}$ There is considerable dispute whether such spillovers lead to an underor over-allocation of resources to municipal services. ${ }^{53}$ Nevertheless, it is generally acknowledged that in theory they lead to a non-optimal allocation of resources and that in practice they may cause substantial inefficiencies.

Resolution of such spillover problems requires some method for internalizing costs and benefits within each political unit. While the specific elements of any particular solution are often complex, spillover inefficiencies are best remedied by intergovernmental transfers, user charges, or redefinition of political boundaries..$^{5+}$ In any case,

49. For example, while within a political unit non-residents may tratel on its streets, make use of its cultural and recreational facilities, and be protected by its police and fire departments.

50. The impact of health- and safety-related services is not readily confined to political boundaries. For example, reducing the risk of contagious discase in one unit will have similar effects in neighboring units. Insofar as education reduces crime, increases social stability, and the like, its benefits will also spread bejond political unit boundaries.

51. Education spillovers may be particularly substantial in that many adult residents may have been educated elsewhere (spill-ins) and many current students may' reside elsewhere as adults (spill-outs).

52. Other types of cost spillovers also cxist. For example, if a political unit in. creases its crime prevention efforts, it may cause criminals to pursue their activities in neighboring units.

In addition to this allocative effect, spillovers may also cause a redistribution of income. Thus, while the evidence is not clear, it is often asserted that central cities are exploited in the sense that they provide services enjojed, but not paid for, by suburban residents. Of course, these benefit spillovers must be balanced against various cost spillovers before assessing the extent and direction of this form of exploitation. For a recent study of Detroit which concludes that net spillouts, while they do exist, may be less than normally assumed, see Neenan, Suburban-Central City Exploitation Thesis: One City's Tale, 23 NaT'L Tax J. 117 (1970).

53. See, e.g., Williams, The Optimal Provision of Public Coods in a Systcm of Local Government, 74 J. PoL. EcoN. 18 (1966); Brainard \& Dolbear, The Possibility of Oversupply of Local Public Goods: A Critical Note, i5 J. Pol. Ecox, 91 (1967); Williams, The Possibility of Oversupply of Public Goods: A Rejoinder, $75 \mathrm{~J}$. POL. Ecos. 91 (1957); Pauly, Optimality, Public Goods, and Local Governments: A General Theoretical Analysis, $78 \mathrm{~J}$. POL. EcoN. 572 (1970).

54. Spillovers have received a great deal of attention. See, c.g., notes 32.53 supra; The ANalysis of Public Output (Míargolis ed. 1970). 
while they are of great practical consequence, benefit and cost spillovers have no direct bearing on inequalities between political units in the availability of municipal services. Consequently, a judiciallyimposed standard of per capita equality is not likely to constitute an efficient resolution of the problem.

\section{Intraunit Inequalities}

For a variety of reasons, it is likely that a given political unit will contain many benefit areas. ${ }^{55}$ Situations of intraunit inequality then become possible, if not inevitable. ${ }^{56}$ This may merely mean that the number of choices confronting the individual is not limited to the number of independent political units: ${ }^{57}$ A single unit can offer different "bundles" of municipal services, thereby realizing the gains derived from unification while simultaneously preserving the situation that would prevail if the unit were divided into autonomous neighborhoods. Each individual must then locate in that area which most closely approximates his preferences-in conformity with the basic model as described in Part I.

Residents of a single political unit, if it is thus to accommodate different aggregate demand levels ${ }^{58}$ without causing a redistribution of in-

55. It is often possible to realize various technological and administrative economies of scale by grouping benefit areas into a single political unit, and different components of a municipal service may have different benefit areas. For example, patrolmen cover small neighborhoods, while detectives may be involved in city-wide activitics; the optimal size for a secondary school is three to four times that of an elementary school. More. over, as indicated at notes 28.29 supra, certain local public goods and services have no necessary geographic dimension other than that imposed by public provision and "frec" access. Finally, political units may reflect social preferences for community size which bear no relation to allocative considerations. These issues are treated extensively in $C$. Shour, supra note 14, at 51-204. See also W. Hirscit, supra note 14, at 167-84. Ticbout expressly acknowledged such technological considerations in A Pure Theory of Local Expenditures, supra note 31, at 419-20. In An Economic Theory of Fiscal Decentraliza. tion, supra note 31 , he provided a theoretical discussion of optimal community size in terms of various technological considerations.

56. Intra-unit inequalities are inevitable with respect to those municipal services distant from the user. Thus, for example, the further away an individual lives from a public park, the more costly it is to use that facility. In such a situation, a standard of per capita equality is meaningless.

57. See p. 104 infra. This increase in the number of alternative choices is particu. larly important once limits on mobility imposed by employment opportunities are recognized. See notc 35 supra.

58. It would, of course, be possible to maintain a standard of aggregate per capita equality while permitting variations in the composition of the "equivalent bundles." III such situations, if the courts focus their attention on the unequal provision of specific services, they are likely to overlook offsetting incqualities in the provision of others. Ostensible equalization may simply introduce or exacerbate incqualitics, ratlicr than eliminate them. A standard of aggregale per capita cquality would permit choice antong different "bundles" of comparable inagnitude; the alternative would scein to involve per capita equality for each and every municipal service, not simply those brought to the attention of the courts by complaining partics.

Ratner, supra note 9, has been one of the few commentators to recognize this issue. 
come, ${ }^{59}$ must be allowed to alter payments to reflect different amounts of municipal services. It is precisely this mechanism that is involved when neighborhoods within a political unit subject themselves to special assessments for additional services. ${ }^{00}$ Residents in a particular benefit area simply agree to purchase additional municipal services from their political unit and are taxed accordingly. This is similar to the situation where one autonomous political unit purchases various services from another, ${ }^{61}$ and conforms to the basic model described in Part I. At the same time, it highlights the impact of a judiciallyimposed standard of per capita equality: That standard either denies some neighborhoods the right to assess themselves for additional services, or requires other neighborhoods to subject themselves to assessments for unwanted amounts.

Similar results obtain if municipal services are provided to benefit areas on the basis of their contributions to revenues. Such an approach does not differ in effect from a special assessment procedure, nor from the result which would obtain if each benefit area functioned as an autonomous political unit. ${ }^{02}$

He "assumes that the equal protection clause requires independent equal protection with respect to the provision of each basic type of municipal service, so that a city could not claim constitutional compliance by providing municipal services which were in some sense equal overall, but unequal neighborhood by neighborhood with respect to any given service... Id. at 40 , n.158. Yet he provides no rationale for his assumption and makes no mention of any countervailing considerations.

Schoettle, supra note 10 , provides another rationale for not mandating service-by-service equality, in addition to the notion of allocative efficiency treated in the text. He argues that there are alternative ways of spending public funds nominally allocated to editeation, and that purchase of related municipal services may enhance educational outputs. Consequently, mandating strict equality may be technologically inefficient in that identical sums could be used to attain higher output lesels for each member of the political unit. Id. at 1388.93.

59. See note 25 supra.

60. See note 132 infra.

61. It is not unusual for small, independent political units bordering on larger ones to purchase services such as sanitation and police and fire protection from the latter. A neighborhood which subjects itself to special assessments could be viewed as an autonomous political unit. While the process does not change regardless of classification, the status of special assessment districts would be crucial if the courts consider only intra-unit inequalities. See p. 114 infra.

62. This may have a substantial bearing on the impact of judicial intervention. See pp. 112-15 infra. In the present context, one difference in these approaches should be noted. Unlike other situations where the amount provided each benefit area is determined by a single revenue scheme, the individual benefit areas do not establish their consumption levels independently. The "independent choice" outcome vould be duplicated only insofar as the political process was able to define an appropriate revelue scheme. The most convenient assumption would be that the demand for municipal services relative to the demand for all other goods and services does not change as income changes. In this, case, it would be appropriate to levy a proportional tax and distribute municipal services to each benefit area in direct ratio to its contribution to revenues. In effect, local public goods and services would be financed as pure public goods and services within benefit areas; between benefit areas they would be finaneed as private goods and services. See note 29 supra. On the other hand, in a situation of 
Indeed it would seem that, all other things equal, ${ }^{\text {o3 }}$ allocation of municipal services to benefit areas on the basis of each area's financial contribution-whether that contribution takes place through special assessments or through a centralized system of taxation-represents the efficient approach. ${ }^{64}$ In response, it might be argued that benefit areas within a political unit are seldom well defined, ${ }^{65}$ and that consequently it will be extremely difficult to develop an accurate balance between financial contributions and the benefits derived from provision of municipal services. ${ }^{00}$ Yet per capita equalization is hardly an appropriate means of dealing with this difficulty. ${ }^{67}$

Furthermore, if private real estate markets are operating properly, some-if not all-of any imbalance between contributions and benefits will be compensated for through capitalization of the excess cost or value of municipal services into the price of land. Where taxes equal benefits, net capitalization will be zero. But where taxes are higher or lower than the benefits associated with the property, ${ }^{08}$ the price of land will be correspondingly lowered or raised. ${ }^{00}$ Consequently a resi-

perfect mobility the choice of a particular revenue scheme is not important, since cach individual is selecting a consumption mix which mets his desires and this latter process itself preserves independent choice.

63. As discussed in Part III infra, there are clearly questions of an in-kind redistribu. tion of income involved.

64. But see note 25 supra. In effect, the revenue scheme sets a "price" and individuals then respond accordingly.

65. The situation is further complicated by the fact that municipal services possess both private and public benefit characteristics, see notes $28-29$ supra, and the level of private benefits desired by any individual may differ substantially from that individual's demand for public benefits. Thus, for example, the private benefits from a public school are confined to those families who send their children to that school. But the bencfit area for the public attributes of the education the school provides-such as increased social stability, a more enlightened citizenry, and increased social productivity-may affect a much larger area. Consequently, an individual may desire one type of cducation for himself and another for individuals in the community at large. His contribution to revenues will go to provide both types of benefits, and exclusive attention to cither would lead to a misallocation of resources.

66. It might also be argued that allowing intra-unit inequalities would provide an opportunity for political abuse, given the difficulties in determining whether cons. tributions to revenues within any given arca correspond accurately to bencfits re. ceived. That is, it might provide an opportunity for politically powerful scgments of the community to secure disproportionate amounts of services. Bul see note 70 infra.

67. Just as in the case of inter-unit spillovers, pp. 99-100 supra, there is no reason to believe that apparent equality in the direct provision of scrvices would necessarily lead to equality in the actual costs and benefits enjoyed by different areas. And even if it did, of course, the result would be less desirable on efficiency grounds than an approach that provided a broader range of choice. Nor would an attempt at imposing
per capita equality eliminate the problem of political abuse mentioned in note 60 supra, since the core problem would presumably remain-the inability to compare with accuracy the aggregate value of the benefits received by different arcas and thus to determine with certainty whether any favoritism was involved.

68. Local taxes which are not tied to location, such as the sales tax and the city earnings tax, will not be capitalized into residential property values but will stay with the individual as a constant regardless of wherc he resides within the political unit.

69. See Oates, The Effects of Property Taxes and Local Public Spending on Property Values: An Empirical Study of Tax Capitalization and the Tiebout Hypothesis, 77 J. Pot. Econ. 957 (1969); Smith, Property Tax Capitalization in San Francisco, 23 Nat'L TAX J. 177 (1970). 
dent will pay, either through rent or taxes or both, an amount roughly equal to the value of the municipal services he receives. And this, in turn, will result in the efficient allocation of those services."

As a final point, it should be noted that if the courts mandate intra-unit equalization without controlling inter-unit disparities, there will be an increased incentive for wealthier individuals to form their own political units. In the long run this may accentuate rather than diminish the overall pattern of inequality. Such incentive effects will be explored in greater detail below. ${ }^{71}$

\section{B. Barriers to Mobility}

In order for the system to function properly, individuals must be willing and able to express their preferences by moving. Consequently, substantial barriers to residential mobility impose an obvious limitation on the model. ${ }^{72}$ These barriers take many forms. Imperfect knowledge, an insufficient range of available choices, lack of employment opportunities, transactions costs, and racial discrimination are considered below; economic barriers such as exclusionary zoning are treated separately in Part III.

\section{Imperfect Knowledge, Insufficient Choices, Employment Barriers, and Transactions Costs}

These factors presumably combine to prevent realization of an efficient allocation. However, they do not imply that the model should be discarded in favor of a system of per capita equality.

First, reliance on such a system would only exacerbate the problems posed by imperfect knowledge. In effect, it would transform municipal services into pure public services: By ignoring individual preferences under decentralized distribution, it would become necessary to deter-

70. Allocative efficiency will result from the fact that, given any geographic pattern of local public goods and services, each individual will seck to reside at a point where the local taxes plus the net capitalization of the value of services into the price he pays for his residence equals the marginal value of those services to him. $10 \mathrm{Or}$, more generally, he will seek to reside where the price he pays for his home plus his taxes equals the marginal value to him of the residence and the services associated with it.) See note 25 supra. The fact that part of the price an individual pays for local public goods and services may go, not to the government, but rather to the person from whom he buys or rents his home does not necessarily affeet this result. It might, however, have an effect on the distribution of income. When additional senices are provided to an area without a corresponding increase in taxes, property values in that area will go up and current landowners will reccive $a$ windfall gain.

Note that it is the windfall gains described here that are the subject of the potential political abuses mentioned in note 66 supra. Consequently, only those owners at the time of the initial abuse will benefit. Subsequent residents will be forced to pay for the additional benefits they receive.

71. See pp. 113-15 infra.

72. See the list of assumptions relied on by Tiebout, note 33 supra. 
mine such preferences through one combined political process. ${ }^{73}$ Like any centralized decision-making process, this involves information costs avoided in the private market through the direct exercise of individual preferences. ${ }^{74}$

Second, in a finite world, the number of alternative mixes of municipal services is limited. This situation is further aggravated by employment considerations which prevent the individual from simply choos. ing his preferred mix of services. ${ }^{75}$ However, reliance on a standard of per capita equality would not resolve these difficulties; rather, it would simply restrict choice even further.

Finally, while transactions costs do have an impact on relocation decisions, they represent simply one element of total cost-an element which is common to all purchases, both public and private. There are, of course, individuals at the margin who will choose to pay the total costs associated with selection of a particular level of municipal services; efficiency criteria suggest that they be allowed to do so. While the conclusion might be different if transactions costs effectively eliminated residential mobility, ${ }^{76}$ individuals in fact move quite frequently. ${ }^{77}$ Admittedly, this mobility occurs in response to employment opportunities and neighborhood characteristics, as well as in response to the availability of municipal services; ${ }^{78}$ nonetheless, it cloes indicate that transactions cost barriers to mobility are not overwhelming.

73. See p. 94 supra.

74. The marketplace model of the private sector also assumes perfect knowledge, and deviations cause difficulties comparable to those under the Tiebout Hypothesis. In both cases, however, each individual can improve his well-being by increasing his knowledge of available alternatives, and consequently has incentives to do so.

75. This difficulty is partially mitigated by permitting intratunit disparities. Sec pp. 100-03 supra.

76. Even if no individual ever changed his place of residence, it could still be main. tained that local political autonomy as a value in itself justifies leaving decisions as to the consumption of municipal services to the local community. Where the courts have hesitated to call for per capita equality, it has largely been to preserve such autonomy. See, e.g., Serrano, 5 Cal. 3d at 610-11, 487 P.2d at 1260, 96 Cal. Rptr. at 620; Robinson, 287 A.2d at 214; Rodriguez, 337 F. Supp. at 284; Van Dusartz, 334 F. Supp. at 876.

77. For example, between March 1969 and March 1970 , over 19 per cent of all individuals changed residence; the average tenure in a single residence was sixty+threc months. See U.S. Bureau of the Census, Mobility of Poruiation in the United StatesMARCH 1969 To MARCH 1970, P-20 No. 210, at 7 (January 15, 1970).

78. Even if it were assumed that individuals initially decided to relocate in order to exploit employment opportunities or to reside with a particular social group, this would not undermine the local public sector locational processes described above. Rather, once a decision to relocate had been made on the basis of private scctor considerations, the individual would then select that place of residence mecting those needs and also conforming most closely to his preferences for municipal services. In practice, there will be trade-offs among location-related factors. An individual may forego private sector preferences in order to attain public sector wants. Thus, in making a locational decision, each individual will maximize his welfare simultancously with respect to employment opportunities, neighborhood characteristics, and consumption of municipal services. Note, however, that this process may gencrate incfficiencics as described at pp. 106.08 infra. 


\section{Racial Discrimination}

Racially motivated barriers to residential mobility"is also influence the distribution of municipal services. If members of a racial minority are prohibited from residing in a political unit completely, or are limited to circumscribed areas of the unit, ${ }^{80}$ it is then possible to force that group to accept undesired levels of municipal services. These levels may be either too high or too low, and such a policy may or may not benefit other members of the political unit. It will, however, prevent individual members of the disfavored group from choosing to "purchase," via locational decisions, desired levels of services. ${ }^{81}$ If the minority is confined to limited sections of a single political unit, it is also possible that others within that unit are "expropriating" resources contributed by the former. ${ }^{32}$

By removing such barriers, the courts will enhance the welfare of the victims of discrimination: Opportunities for choice will be increased, and it will no longer be possible to expropriate resources contributed by the minority residents. Insofar as the elimination of these barriers merely expands the range of choices, the economic wellbeing of other residents will not be reduced. ${ }^{83}$ Where the elimination of barriers reduces the level of expropriation, it does impose a cost on others-but a cost which the courts should not be reluctant to demand.

79. Problems of income-based restraints on mobility are considered in Part III in/ra.

80. See, e.g., K. Taeuber \& A. Taeuber, Negroes in Cities: Residential Secregation aNd Neighborhood Change (1965).

81. On the basis of the capitalization concept treated at pp. 102.03 supra, the munici. pal services provided minority areas will be distributed efficiently among the residents regardless of whether the total amount is optimal.

82. Property owners may also derive excess profits from the cxistence of a separate housing market.

83. Racial integration, without more, will not reduce the amounts of municipal services formerly available in segregated communities. If racial integration brings with it integration by income, however, the situation is somewhat changed. See Part III infra. Shifting demand patterns, resulting from increased mobility, may also affect real estate prices.

If individuals prefer to live in racially segregated communities, then their welfare is reduced if racial barriers are removed. This may also cause a reduction in property values and thereby impose a secondary monetary cost. Nonctheless, both courts and the legislatures have gone quite far in striking down overt racial barriers to mobility. See, e.g., Jones v. Alfred H. Mayer Co., 392 U.S. 409 (1968), relying on the Cisil Rights Act of 1866, 42 U.S.C. $\$ 1982$ (1970). It is difficult to assess the "efficiency" of these decisions from an economic perspective, since they impose a cost on one group while benefiting another, and neither the costs nor the benefits are casily quantified. Indeed, the whole issue may better be viewed as a question of the definition of property rights, and hence of the distribution of income. See Calabresi \& Mlamed, Property Rules. Liability Rules, and Inalienability: One I'iez' of the Cathedral, 85 HAns. L. REv. 10s9. 1098 (1972). From a purely allocative standpoint, alternative approaches would be to permit complete mobility but compensate those perceiving themselves as damaged thereby, or to permit segregated neighborhoods but require residents to maintain that situation by "buying off" those secking entry. Yet practical and moral difficultics in establishing appropriate prices, high transactions costs, the "frec-rider" problem. and the Thirteenth and Fourteenth Amendments, would render these monetary solutions un. tenable. 
It may be urged that "open housing" is a long-term if not an unattainable goal, and that the courts must therefore intervene directly in the distribution patterns for municipal services. This argument has considerable force in the context of exploitative racial discrimination, and some judicial adjustment of distribution patterns may be required. But a standard of per capita equality still seems inappropriate. In theory, effective intervention would require that the courts first determine the consumption preferences of, and revenue contributions by, minority groups. Given the impossibility of deriving such information, it is convenient to assume equivalence between all racial groups of the same income class. It then becomes reasonable to impose a standard of per capita equality only as between these groups. ${ }^{84}$

The only alternative to equalization by income class is across-theboard equality, a standard which is generally undesirable for the reasons explored above. ${ }^{8 \bar{s}} \mathrm{~A}$ solution other than these two-that is, an approach which would upgrade the services available to minorities to a level which is either above or below that prevailing for all others of comparable income-would, in the short run, simply perpetuate disparities based solely on race, ${ }^{86}$ leaving the courts in a difficult position in terms of doctrine and equity. In the long run, market forces would probably compel the courts to select one of the two standards just mentioned. ${ }^{87}$

\section{Fiscal Externalities}

In developing his model, Tiebout assumed that each individual was living on unearned income, ${ }^{88}$ and that he could therefore ignore private sector locational considerations. Moreover, while describing the

84. Even this approach would pose substantial measurement difficulties in situations where there was no stratification by income. Presumably, it would be necessiry to derive some average availability figure.

85. See pp. $95-98$ supra.

86. In those cases involving equalization by race, see note 11 stupra, the courts have not directly confronted this dilemma. Presumably, this has bect because the white areas of town were receiving uniform levels of serviccs. However, thesc suits have involved small towns, with the exception of Norwalk CORE (where equalization was between whites and non-whites of the same economic class) and Hobson (where the court implicitly called for a standard of per capita equality regardless of racial con. siderations). As suits challenging distribution patterns in large cities begin to arisc, it is unlikely that the courts will be able to avoid this issue.

87. This could result, in part, from the operation of private real cstate markets. Pre. sumably, those areas which were upgraded would increase in value, and the relatively low income residents would be "driven" back into areas with lower service levels. "The courts would then be faced with the choice of re-imposing their standard, or allowing the equalization by income class to remain in effect. Repeated choice of the former would ultimately lead to per capita equality.

88. See note 33 supra. 
means by which municipal services were distributed, Tiebout never explicitly examined appropriate funding arrangements. ${ }^{80}$

In a recent article, James Buchanan and Charles Goetz suggest that these two factors may detract from the efficiency of the equilibrium reached under the processes Tiebout described. ${ }^{30}$ The difficulties arise largely from the existence of "fiscal externalities." That is, the movement of an individual into or out of a community may impose on the other members of that community a net gain (external benefit) or loss (external cost) with respect to the municipal services they enjoy. For example, the individual may contribute to local taxes without requiring the production of any additional goods and services-as would be the case if the goods and services were purely public within the community. ${ }^{91}$ In that case, his presence would simply reduce the tax bill of all the other residents. Conversely, the community he leaves will suffer a reduction in tax revenues without a corresponding reduction in the cost of the pure local public goods and services. Alternatively, if the goods and services involved were not purely public, in-migration could have a "congestion effect." That is, the individual's presence could reduce the benefits available to all other individuals to a degree not offset by his contribution to revenues. ${ }^{92}$ Yet, in choosing a community in which to reside, the individual will generally ignore these costs and benefits he confers on others and will simply locate where the value he derives from municipal services and from private sector activities-such as employment-is at a combined maximum. The result will be a non-optimal distribution of the population, since it would be possible to enhance the welfare of everyone by altering the individual's choice. ${ }^{93}$

The only way to avoid these inefficiencies is to develop a means whereby the individual is forced to take account of his effect on others. Buchanan and Goetz suggest that this will occur only if the political unit can engage in discriminatory taxation to recover the differential gains enjoyed by various individuals as a result of their location. ${ }^{04}$ It is unlikely, however, that any local government would, or even could, develop such a system of taxation.

89. See note 40 supra and pp. 115-21 infra.

90. Buchanan \& Goetz, Efficiency Limits of Fiscal Mobility: An Assessment of the Tiebout Model, 1 J. PuB. ECoN. 25 (1972).

91. See the discussion of purely public goods at pp. $93-95$ supra.

92. Such fiscal externalities are discussed in another context at pp. $115 \cdot 21$ infra.

93. As Buchanan and Goetz note, the inefficiencies are to some extent related to the existence of differences among political units in terms of the private sector opportunities available to an individual.

94. Buchanan \& Goetz, supra note 90 , at 34-39. 
However, it does not appear that this difficulty, any more than the real-world deviations from the other assumptions underlying the Tiebout model, justifies a standard of per capita equality. ${ }^{.5}$ Equalization would resolve cost externalities problems only with centralized financing, ${ }^{96}$ would not alleviate congestion externalities in the case of impure local public goods, ${ }^{97}$ and would eliminate efficiencies generated by the choice mechanism. This seems to be the view of Buchanan and Goetz, who conclude by suggesting that the virtues of the Tieboutprocess are to be preferred

if the alternative to fiscal decentralization in the provision of spacially-limited nonexcludable goods and services should be increased fiscal concentration at central government levels.98

\section{Inequalities of Income}

We have proceeded thus far on the assumption that the distribution of income is to be accepted as given. Substantial inequalities do exist, however, and they have considerable impact on the distribution of municipal services.

\section{A. In-Kind Redistribution}

The clear implication of the Tiebout Hypothesis is that "unequal" distribution of municipal services enhances each individual's welfare by permitting, indeed requiring, independent choice of consumption levels. Without more, judicial imposition of a standard of per capita equality has the effect-although presumably not the purpose-of reducing the welfare of all individuals. Why, then, do equalization suits arise? The answer is that the groups petitioning for equalization are seeking a redistribution of income, which will occur when the complaining group bears less than the full costs of equalization.

Generally, in-kind transfers are an inefficient method of redistribu-

95. Although Buchanan and Goetz do not discuss the point, it would appear that the capitalization process described at pp. 102-03 supra would operate on an inter-unit as well as an intra-unit basis, and consequently would act to mitigate the incfficicncies described above.

96. With an equal level of services in all communitics and centralized financing, neither the services received by an individual nor the payment for them would be affected by the movements of any other individual.

97. An equal level of services with centralized financing would presumably climinatc all incentives to relocate in response to public sector considerations. However, in re. locating in response to private sector considerations, the individual still would not consider the congestion effects of his decision.

98. Buchanan \& Goetz, supra note 90 , at 40 . 
tion. That is, assuming the amount of the transfer has been fixed, all those involved would prefer that it occur in the form of a straight cash payment, rather than through a judicially-imposed standard of per capita equality. Despite this general rule, there may be grounds for redistributing certain goods and services under particular circumstances. ${ }^{99}$ Nevertheless, in such instances there is no a priori basis for using per capita equality as the appropriate redistributive standard. Moreover, regardless of how it is justified, that standard is likely to be ineffective, if not counter-productive.

\section{Redistributive Standards}

Certain local public goods and services may possess particular characteristics justifying deviations from distribution patterns produced by market forces. In some cases, redistributive claims of this type provide a persuasive objection to results obtained under the Tiebout Hypothesis.

Governmental redistribution can be explained in large measure ${ }^{100}$ on grounds that those relinquishing resources are compensated in some form other than money or money's worth-be it psychic gratification, a sense of moral well-being, enhanced social stability, aggregate economic growth, or vicarious pleasure derived from consumption by others. ${ }^{101}$ Such redistribution may involve either money or specific goods and services. In either case, redistribution is not only consistent with, but also necessary for, allocative efficiency. The welfare of recipients is clearly increased, while those relinquishing resources presumably do so because it is perceived as enhancing their own welfare. ${ }^{102}$ The choice of an optimal level of redistribution is therefore open to the same type of analysis used to determine the proper allocation of resources to other pure public goods and services. ${ }^{103}$ Consequently, it is necessary to estab.

99. Inefficiencies may also be disregarded if redistribution per se is accepted as a legitimate judicial function though it is acknowledged that the courts cannot compel outright dollar transfers. A standard of per capita equality may then be vievied as a second best alternative.

100. Perhaps the most plausible alternative to the explanation which follows is that a coalition of lower income individuals and the well-intentiuned vealthy impose a redistributive scheme on the rest of society. While this process also plays a role in reality, it is disregarded here on the assumption that it provides no independent justifi. cation for judicial intervention. At a minimum, it is presumed that the courts must find some rationale for acting out their good intentions.

101. Thus, viewed from this perspective, there is no "redistribution" involved in the sense that the total welfare of one group is enhanced at the expense of the total velfare of another group. Rather, one is simply taking account of the public benefit areas for particular goods and services.

102. See note 100 supra.

103. See, e.g., Thurrow, The Income Distribution as a Pure Public Good, 8j Q.J. EcoN. 328 (1971). While approaching the question from a somewhat similar perspective, 
lish a political process for determining the appropriate extent and form of redistribution. ${ }^{104}$ Viewed from this perspective, the optimal pattern of distribution is an allocative problem requiring a political solution, and there is no basis for judicial intervention in the redistributive process.

It may be argued, however, that certain distributional standards have been placed outside the realm of politics, and that the courts are responsible for their enforcement. Thus, it may be asserted that each individual has a fundamental right to certain goods and services apart from the momentary interests of the rest of the society in providing them. ${ }^{105}$ The basis for this assertion must, however, go to the character of a particular good or service, and not to the process of allocation. A particular allocative process is introduced in the first instance for reasons of efficiency; there is no a priori basis for asserting that those goods and services typically provided by local governments are neces. sarily the same goods and services to which each person has a fundamental claim. ${ }^{100}$

Judicial intervention must therefore be predicated on a finding that the character of a particular good or service is such that all individuals have a right to its enjoyment. But this is only the beginning. It then becomes necessary to specify an appropriate mandatory distribution pattern.

There are two basic alternatives: a guaranteed minimum or per capita equality. ${ }^{107}$ In choosing between the two, the particular char-

Hochman \& Rogers, Pareto Optimal Redistribution, 59 AM. Econ. REv. 542 (1969), argue that private market-type bargaining arrangements could lead to an optimal solution. Nonetheless, they do acknowledge some need for a supervening authority to regulate the process. It would appear that a political process would be necessary as the number of persons involved increased beyond their hypothetical two-person community. See Gold. farb, Pareto Optimal Redistribution: Comment, 60 Ax. EcoN. Rev. 994 (1970); Polinsky, Shortsightedness and Nonmarginal Pareto Optimal Redistribution, 61 AM. EcoN. REv. 972 (1971).

104. See pp. 93-95 supra.

105. See J. RAwLs, A Theory of Justice (1971), for an argument that all individuals should have a fundamental right to certain (very general) "primary goods" which are essential to any person's well-being.

106. Food, shelter and legal services possess predominantly private characteristics. Nonetheless, in some measure these goods are provided to low income persons as part of a politically determined redistributive process. Many would go one step further and argue that access to these goods is a fundamental right which should be protected by the courts. See, e.g., Michelman, The Advent of $A$ Right to Housing: A Current Ap. praisal, 5 Harv. Civ. Rights-Civ. Lib. L. Rev. 207 (1970).

107. Other possible standards may be based on need and/or on a permissible range of disparities. The need criterion raises issues identical to those posed by differences in input/output ratios. See p. 112 infra. For example, the assertion that the cdica. tional needs of low income and minority students are greater than those of their wealthy white counterparts is simply another way of saying that greater resources are repuircd to ensure comparable achievement by the former class of students; likewise, greatcr necd 
acteristics of the good or service in question will again be important. A guaranteed minimum, ${ }^{108}$ for example, seems most appropriate where the good or service is enjoyed by each individual independently of the consumption levels of others. Thus, certain minimum amounts of food and shelter are necessary simply to insure survival, and they confer this advantage quite independently of whether or not other persons are similarly provisioned. ${ }^{109}$ Perhaps this factor is also relevant to the guaranteed minimum standard implicit in the decisions establishing the right to counsel in criminal cases. ${ }^{110}$ On the other hand, a standard of per capita equality seems most appropriate where the essence of the right is relational. An obvious example is the right to vote: The value of one individual's vote has meaning only in relationship to the value of another's vote. This perhaps provides a rationale for the Supreme Court's standard of per capita equality in the "one-man-one vote" rule. ${ }^{111}$ Sometimes, of course, the appropriate characterization of a particular good or service is subject to debate. In the context of municipal services, education provides the most interesting example. Education may be viewed as a right enjoyed independently by each individual: A certain minimum of education-related skills is essential to "survival" in the society. ${ }^{112}$ Alternatively, education may be viewed as a relational right; the critical factor then is that each individual be given the same educational opportunities. ${ }^{113}$

While allocative processes may not be significant in determining whether access to a particular good or service should be established as a fundamental right, they do have implications for implementing a proper standard for redistribution once that determination is made. Some of these considerations are explored in the next section.

for police protection means simply that greater crime presention resources are necescary in certain areas in order to maintain a uniform level of protection.

A permissible range of disparities standard would be based on the notion that relative disparities are of controlling importance. Thus, for example, this is one basis for a progressive tax structure. It is doubtful that the courts could define and apply such a standard directly to the distribution of local public goods and services. Note, howerer, that in many instances imposition of a minimum standard may be intended, in part, to limit the range of permissible disparities.

108. Professor Michelman has been the leading proponent of this approach. See Michelman, supra note 9, at 33.

109. This is the approach embodied in a wide range of governmentally sponsored transfer programs, including food stamps, welfare payments, housing supplements, and the like.

110. See, e.g., Douglas v. California, 372 U.S. 353 (1963).

111. See, e.g., Reynolds v. Sims, 377 U.S. 533 (1964).

112. This appears to be the implicit judgment embodied in public educational finance schemes which provide a flat minimum grant to all districts.

113. This is the viewpoint adopted by a variety of commentators. See note 12 supra. 


\section{Ineffective Redistributive Efforts}

Whatever the justification for redistribution, reliance on a standard of per capita equality may well be an ineffective, ${ }^{114}$ if not a coun* ter-productive, redistributive policy.

\section{a. Input-Output Differences}

Commentators have devoted considerable attention to the distinction between expenditures (inputs) and the quality or value of services received (outputs) in the provision of municipal services. ${ }^{110}$ In the present context, ${ }^{116}$ it is sufficient to note that equalization of expenditures will generally result in relatively lower output levels in areas characterized by high population density, substandard dwellings, and low income residents. ${ }^{117}$ On the other hand, output equalization is rendered extraordinarily difficult by complex problems of definition and measurement, ${ }^{118}$ and may be impossible to achieve in practice. ${ }^{110}$

\section{b. Who Gets the Gains (Or Takes the Losses)?}

As noted above, the net value of municipal services is capitalized into property values. ${ }^{120}$ Consequently, equalization will cause those values to change. The nature of such changes will be determined by various market forces; in general, however, property values will rise in neighborhoods experiencing a relative increase in services and will fall in others.

114. The term "inefficient" is used in its strictly cconomic sense as defincd at p. 92 supra. The term "ineffective" relates to the question of whether and to what extent redistribution favoring the poor occurs, regardless of the efficiency with which it occurs.

115. See, e.g., Ratner, supra note 9, at 1.12, 40.42, 48.49; Schocttle, supra note 10, at 1381-82; Note, $A$ Statistical Analysis, supra note 10, at 1315-19; Comment, The Evolution of Equal Prolection, supra note 9, at 175-76. In Hobson and Serrano the courts relicd on input measures (student and teacher placement and expenditures per capita), while in Norwalk CORE, Hadnot, and Shaw they focused on outputs (effectiveness of services, and quality and quantity of facilities, respectively). Robinson is the one calsc involving cducation which explicitly treats, albeit briefly, output considerations.

116. For discussion of this issue in other contexts, see notes 153,154, 156 and 169 infra.

117. This is particularly true of education, police protection, and sanitation. In addi. tion to authorities cited in note 115 supra, see J. Coleman, et al., EQunlity of EuUCrition. AL Opportunity 312 (1966); W. Hirsch, supra note 14, at 147.65; ON EQUatity of EvU. CATIONAL Opportunity (Mosteller \& Moynihan eds. 1972).

118. For example, is educational output defined in terms of test scores, expected future earnings, or cultural adaptation; and given any such standard, how can it be applied? Likewise, is police protection defined as the probability of being a victim of any given type of crime? Moreover, is equality to be measured in terms of individuals, or in terms of distribution ranges for groups of individuals?

119. Thus the output of certain local public goods may be at best marginally responsive to increases in traditional inputs.

120. See pp. 102.03 supra. Note that any change in property values following equalization will also reflect any alterations in property tax rates necessary to finance the new pattern of services. 
The consequences of this process are quite complex; ${ }^{121}$ the impact of a standard of per capita equality will vary widely depending on the factual setting. In any event, however, property owners in upgraded areas will be primary beneficiaries of the court's largesse':" through windfall increases in the value of their property. These gains to current owners will be realized through higher rental (or resale) charges. It is therefore likely that at least some of the persons the courts are attempting to benefit will be forced to pay for the additional goods and services they receive. The "winners" may be relatively prosperous apartment owners rather than their low income tenants. The question of who is injured by the equalization process is somewhat more uncertain. Nevertheless, at least some of those hit hardest by reduced property values are likely to be lower-middle and middle income residents. ${ }^{123}$

\section{c. Incentive Effects-Flight to the Suburbs}

As explained below, ${ }^{124}$ an individual's cost for municipal services is a function of the income and wealth of his neighbors. This fact provides incentives for individuals to move from poor communities to wealthy ones, and for wealthy communities to engage in exclusionary zoning.

If the courts limit themselves to a standard of per capita equality within political units, these incentives to "suburbanize" will be increased substantially as wealthier individuals seek to increase their consumption of municipal services and to reduce their costs per unit of consumption. The net result will be a loss to central city residents. ${ }^{125}$ This counter-productive impact can be avoided only by enforcing a standard of per capita equality across political boundaries. ${ }^{120}$ Con-

121. Similar processes are involved in the introduction and enforcement of housing codes. Comprehensive treatment of a wide range of issues in that context, which could also be applied to the equalization of municipal services, is contained in Ackerman. Regulating Slum Housing on Behalf of the Poor: Of Housing Codes, Housing Subsidies and Income Redistribution Policy, 80 YALE L.J. 1093 (1971).

122. It is assumed that the owners are not required to bear the costs of equalization.

123. Moreover, none of the judicial opinions to date appear to have specified how equalization is to be financed. If various political units resort to highly regressive tax measures, the burden on lower-middle and middle income groups may be particularly harsh.

124. See pp. 115-21 infra.

125. Lower income central city residents benefit by the presence of upper income residents insofar as it enables the former to reduce their own costs for municipal services. This process was given a precise formulation in Buchanan, Principles of Urbant Fiscal Strategy, 11 Public Chorce 2 (1971).

126. Alternatively, it would be necessary to alter the financing scheme so as to require suburban contributions to central city revenues. See pp. 115.21 infra. 
sequently, the courts cannot adopt a "degree" of change; they are faced with an all-or-nothing situation.

\section{d. Incentive Effects-Resort to Private Markets}

Certain municipal services are susceptible to private market dis. tribution, either directly through individual purchases ${ }^{127}$ or indirectly through special assessment financing. ${ }^{128}$ For high income groups, resort to these mechanisms may be preferable to maintaining widespread per capita equality at high levels throughout the public sector. In part, this would result from attempts by wealthier individuals to reduce the cost of these services, since purchases in the public sector include the additional cost of subsidizing low income recipients. ${ }^{120}$ Perhaps more importantly, it would reflect a desire to purchase quantities above amounts provided by the public sector. ${ }^{130}$ To the extent that a transition of this type occurs, the net result of judicially-imposed standards of per capita equality could well be reduced levels of public sector activity. Existing disparities in the distribution of services could therefore continue, or perhaps even be accentuated.

Thus, exclusive concern with the public sector, even under an ostensible standard of per capita equality, may ultimately result in the defacto imposition of a minimum standard. That is, when individuals can obtain amounts above that provided publicly by resorting to private sector purchases, per capita equality in the public sector becomes a politically determined minimum the courts have not sanctioned and over which they have foresaken all influence. If the purpose of judicial intervention is enforcement of a minimum standard, then the courts should confront that task directly; they should disregard the purchase of additional amounts whether those purchases occur in the form of private or local public expenditures. Alternatively, if the courts feel compelled to impose a standard of per capita equality, or if they intend to eliminate private wealth as a factor in determining access to

127. See note 29 supra.

128. See p. 101 supra.

129. See pp. 108-11 supra.

130. In part, any change-over may be deterred by the fact that those resorting to private sector distribution will also be required to contribute to the cost of publicly distributed goods and services. This will not be a hindrance if individuals can supplement amounts received by the public sector (for example, through use of both public and private cultural and recreational facilities, private crime and fire prevention de. vices, and the like). Barriers do exist, however, if resort to the private scetor entails foregoing publicly distributed goods and services, and thereby necessitates "double payments" (e.g., in the case of education). 
municipal services, ${ }^{131}$ then they must be willing to prohibit or regulate access to private markets. ${ }^{132}$

\section{B. The Financing of Local Public Goods and Services}

Local political units typically obtain funds through percentage levies on residential, commercial, and industrial property; on individual earnings; and on the proceeds from retail sales. These financing schemes share two characteristics which have a substantial impact on the distribution of municipal services. First, the tax base from which such revenues are derived may vary significantly from one community to the next. Consequently, local political units will possess differing fiscal capacities; that is, the same tax rate will generate different revenues in different units. ${ }^{133}$ Second, under such tax schemes different individuals within any given community will contribute different amounts to local revenues depending on their income, wealth, and consumption preferences, even though they receive the same level of services. ${ }^{134}$ These factors have a marked impact on horizontal and

131. Serrano condemned educational financing systems which render "the quality of a child's education a function of the wealth of his parents and neighbors." 5 Cal. $3 d$ at 589, 487 P.2d at 1244, 96 Cal. Rptr. at 604 (cmphasis added). Private sector distribution yields the same result, and may well exacerbate inequalities. To treat these situations dissimilarly is to impose a difference where there is no real distinction.

132. A comparison of Hadnot and Shaw is most instructive in this regard. The court in Hadnot required equalization of recreational facilities funded out of feneral reventies. However, the court refused to order equalization of street pavement, sidewalks, gutters, fire hydrants, street lights, sewerage lines, street signs, and traffic lights, as well as various other services. The court's refusal was based on the fact that these were funded out of special assessment revenues. The court indicated that the differences vere due to the "respective landowners' ability and willingness to pay for the property improsements. This difference ... does not constitute racially discriminatory incquality. The equal protection clause of the Fourteenth Amendment to the Constitution of the United States was not designed to compel uniformity in the face of difference." 309 F. Supp. at 970 (emphasis added). In contrast, the court in Shaw ordered the cqualization of some of the same goods and services (street paving, strect lights, water lines, and scwerage lines) where financed out of general revenues.

The court in McInnis clearly recognized this difficulty:

The more money the latter [wealthy] districts must supply to the former, the less incentive the well-to-do will have to raise their tax rates. If the quality of good public schools declines, affluent children have the option to attend prisate schools. thus completely eliminating the need for the wealthy to raise taxes.

293 F. Supp. at 336.

133. The ensuing discussion is framed in terms of the revenues raised by local political units. The same analysis, however, would be applicable to revenue contributions by different benefit areas within a single unit. Also, as discussed in note 154 in/ra, similar considerations arise in the context of differing input/output ratios within and between political units.

134. While nearly universal in practice, percentage levies are not, of course, the only possible means of local finance. An obvious alternative vould be to cmploy a simple head tax, whereby each individual in the political unit vould be assessed a flat fee for a given level of municipal services. The result would be similar to a tuser charge system as employed in the private sector. See note 37 supra. As discussed in note 
vertical equity, individual and community behavior, and the distribution of income.

\section{The Impact of Local Financing Schemes}

\section{a. Horizontal and Vertical Inequalities}

Inequalities in fiscal capacity may be viewed as the local public sector analog to individual income inequalities in the private sector. Prosperous communities, like prosperous individuals, can purchase more of a good or service with any given percentage expenditure of income or wealth. Without more, this fact of differential purchasing power, or vertical inequality, provides no independent basis for judicial intervention. ${ }^{135}$

However, unlike income inequalities in the private sector, differences in fiscal capacity may also lead to substantial horizontal inequalities. ${ }^{130}$ With respect to private goods and services, individuals with equal incomes possess equal purchasing power. In contrast, as a result of differences in fiscal capacity, individuals with identical incomes and identical preferences may spend equal sums for municipal services, yet receive different amounts. Conversely, individuals with identical incomes and preferences may receive equivalent amounts of such services, yet make different dollar expenditures. Since these differentials do not appear to reflect differences in purchasing power and/or consumption preferences, they seem to lack an allocative rationale.

In the context of the locational processes described by Tiebout, however, differences in fiscal capacity are simply one factor to be considered in making a locational choice. So long as there are no barriers to mobility, an individual will stay in a unit with a lower fiscal capacity only if he is obtaining other locational benefits offsetting the higher

148 infra, the results obtained under such a scheme would be quite different from those described here.

Tiebout himself, unfortunately, never directly addressed the problem of financing schemes. His 1956 discussion may be interpreted as involving a system of flat charges rather than one of percentage levies; the 1961 discussion was framed in terms of percentage levies. Tiebout, supra note 31 .

135. As suggested at pp. 108-11 supra, judicial intervention in the face of vertical inequalities may be justified where access to a particular good or scrvice is considered a fundamental right. As discussed at note 157 infra, however, there are some difficulties in the direct equalization of fiscal capacities as a means of protecting such fundamental rights.

136. An early discussion focusing on horizontal inequalities in the context of local political units, and urging a system of interunit transfers on equitable grounds, may be found in Buchanan, Federalism and Fiscal Equity, 40 AM. Econ. REv. 583 (1950). 
effective costs of municipal services. ${ }^{137}$ As noted above, ${ }^{138}$ the particular trade-off between private and local public services chosen by the individual under these circumstances may not always be optimal from the societal point of view, and consequently the process may not always be efficient. But there is no reason to condemn the result simply because of apparent horizontal inequalities in the local public sector.

\section{b. Individual and Community Incentives}

The standard methods of financing municipal services have considerable impact on the incentives facing individuals and communities. All other things equal, ${ }^{130}$ it will always be to the individual's advantage to locate in the community with the greatest fiscal capacity, since he thereby minimizes his unit costs for each municipal service. As explained above, however, the individual's response to these incentives may not always minimize sociely's costs, and may consequently give rise to inefficiencies. ${ }^{140}$

The same factors also yield certain collective incentives. It will always be to the advantage of a community to encourage residence by relatively wealthy individuals and by commercial and industrial concerns, ${ }^{141}$ since they will generally contribute most to the community's fiscal capacity. Moreover, the goods and services offered by a local political unit are often not purely public even within its own boundaries. ${ }^{142}$ It will therefore be to the community's advantage to go even further and completely exclude relatively poor residents through methods such as exclusionary zoning, ${ }^{1+3}$ since such residents are likely to require

137. On the other hand, where there are substantial barriers to mobility such as ex. tremely high relocation costs, there may be substantial horizontal inequalities in the local public sector which are not compensated for by other locational adsantages, such as better employment opportunities.

It should be noted that exclusionary zoning, though clcarly a substantial barricr to mobility, is unlikely to result in such uncompensated horizontal incqualities, since its tendency is to induce economic stratification of communities, and thus to insure that individuals of the same income class live in communities with similar fiseal capacities.

138. See pp. 106-08 supra.

139. In practice, the individual simultancously secks to maximize his welfare with respect to the costs and benefits of both private and public goods and services. Con. sequently, an individual will accept higher effective costs per unit of municipal services if he is obtaining offsetting benefits from location in a particular area.

140. See pp. 106-08 supra.

141. This assumes that the industrial and commercial concerns contribute more in revenues than they impose in costs. These costs may involve need for additional local public goods and services as well as spillovers such as noise and air pollution.

142. See notes $28-29$ supra.

143. Exclusionary zoning may be viewed as a public sector analog to tie-ins in the private sector. That is, the purchase of municipal services must be accompanied by the purchase of a large lot and an expensive residence. But since communities are not competing for residents per se, there are no public sector incentives to alter this system. Con. sequently, if it is to be altered at all, it must be altered by the courts. 
additional services which exceed in cost the increase in local revenues. ${ }^{144}$ On the one hand, such exclusionary activity by communities may offset the tendencies described above ${ }^{14 \pi}$ to over-populate certain areas, and may thereby serve an efficiency generating function. ${ }^{140}$ On the other hand, highly restrictive zoning policies may lead to a misallo. cation of resources. ${ }^{1+7}$ They also act as a considerable restraint on mobility, and thus choice, for the less prosperous members of society, and are likely to result in stratification of political units by economic class. ${ }^{148}$

\section{c. The Distribution of Wealth}

Individual and community responses to the incentives described above may have a substantial impact on the distribution of wealth. In terms of the financing and distribution of municipal services, an increase in exclusionary practices and a consequent decrease in mobility ${ }^{140}$ will generally enhance the welfare of the already prosperous at the expense of the relatively poor, while a decline in exclusion and an increase in mobility will have just the opposite result. ${ }^{\text {wo }}$ Moreover,

144. The costs imposed by in-migrants may include other factors besides the provision of municipal services. In particular, they may include perceived losses associated with curtailment of neighborhood homogeneity.

145. See pp. 106-08 supra.

146. Davis \& Whinston, The Economics of Complex Systems: The Case of Municipal Zoning, 17 Krklos 419 (1964), demonstrates that zoning is necessary to achieve Parcto optimality where the value of one site depends upon the character of adjoining sites. This does not, however, dispose of the distributional question, namely, whether the excluding group should compensate those being excluded. Indeed, under an effective system of compensation, exclusionary zoning would be unnecessary.

147. Note, Large Lot Zoning, 78 YALE L.J. 1418 (1969), suggests that exclusionary zoning may lead to inefficient utilization of suburban resources. Crecine, Davis \& Jacksoli, Urban Property Markets: Some Empirical Results and Their Implications for Municipal Zoning, $10 \mathrm{~J}$. LAw \& ECON. 79 (1967), suggests that the supposed interdependence justify. ing zoning practices may not be as prevalent as assumed.

148. If municipal services were financed with a head tax rather than with percentage levies, see note 134 supra, there would be no fiscal incentive for cxclusionary zoning. Communities would presumably admit anyone who was prepared to pay the local fec. Similarly, individuals would find their choice of community unaffected by the relative personal wealth of its residents, though they would prestumably still be sensitive to the relative size of the industrial and commercial tax base, and to the fiscal externalities resulting from such factors as differences in community size, discussed at pp. 106.08 supra.

149. That is, a decrease in the mobility of the poor. The impact of exclusionary zon. ing on an individual's mobility will obviously decline as his wealth and income increase.

150. The effect in terms of municipal services is clear if it is assumed that local political units generate all of their revenues from proportional or progressive taxes on personal wealth and income, and that exclusionary zoning leads to stratification of political units by economic class. While relaxation of these assumptions to bring them into line with reality would bring a corresponding decrease in the distributional effects described, it would be unlikely to reverse those effects. Thus, municipal services are financed in part out of revenues from business taxes, and the sources of such taxes arc clearly not distributed among communities in direct proportion to the personal wealth of their residents. See p. 120 infra. Further, the elimination of exclusionary zoning is 
these distributional effects may be reinforced by other factors which are only indirectly related to the provision of municipal services. Exclusionary practices may prevent low income persons from selecting optimal locations for private employment and consumption opportunities. ${ }^{151}$ Conversely, communities which engage in exclusionary zoningwhich will inevitably be the wealthier communities-frequently obtain aesthetic, social, and economic benefits ${ }^{152}$ quite apart from the protection of fiscal capacity. ${ }^{\mathbf{1 5 3}}$ Enhanced mobility for the poor would reverse these consequences as well. ${ }^{154}$

\section{Adjustment Alternatives}

There are at least three responses to the effects of local financing schemes. First, it is arguable that the status quo represents a satisfactory state of affairs. This position assumes that vertical inequalities are an accepted element in the market for municipal services and that any horizontal inequalities are resolved through individual locational choices. It also accepts barriers to mobility as simply one aspect of local political autonomy, and presumably views the latter as an interest which takes precedence over the individual's stake in residential mobility. Finally, it retains any efficiency effects, both positive and negative, resulting from exclusionary zoning and individual responses to fiscal incentives.

A second response would be to introduce some system of fiscal capacity equalizing-that is, a system which would ensure that a given tax

unlikely to lead to a complete mixture of the rich and the poor in residential com. munities; cohesion by economic class will undoubtedly continue to some cxtent. Still, increased mobility for the poor could hardly work to their disadvantage.

151. For example, it may prevent such persons from following emplojment opportunities to the suburbs. In this respect, cxclusionary zoning may simply be ineflicient in that it may prevent in-migration even by those individuals whose net lomtional gain would exceed the community's loss in fiscal capacity, and who would therefore be willing to compensate the community for any loss it would suffer.

152. Thus, large-Iot zoning may result in a visual and social homogeneity which residents find pleasing, or may lead to particularly low levels of noise and waste pollution.

153. Indeed, in many cases such considerations, rather than fiscal incentives, may be the primary motive for restrictive zoning practices.

154. Variations among political units, or among benefit areas within political units. in terms of input/output ratios-that is, in terms of the ultimate value of an output, such as educational advancement or effectiveness of police protection, per dollar of input-will lead to much the same effects as have been deseribed here for variations in community wealth. Indeed, the former may be of greater practical significance, particularly with respect to education and police protection. Thus, individuals will have an in. centive to move into communities where, because of social, political, geographic, or other factors, their taxes will be most efficient in securing municipal services. Likewise, communities will have an incentive to erect barriers to in-migration by those persons whose presence might undermine the effectiveness of the existing systens for delivery of such services. Parallel problems of horizontal equity and distribution of wealth will also arise. 
rate generates the same amount of revenue per capita in every political unit, while still allowing each unit to establish its own tax rate. ${ }^{105}$ This approach eliminates variations in community wealth as an incentive for either individual mobility or exclusionary zoning. It would not, however, interfere with exclusionary zoning policies motivated by other considerations, although it would compensate-at lenst in part-those whose mobility was curtailed by such devices. ${ }^{160}$ Moreover, because equalization of fiscal capacities requires the transfer of funds between political units, it will result in some redistribution. ${ }^{157}$ Because existing tax bases are not always directly correlated with the relative wealth of the community's residents, however, the clirection of these transfers as between income classes is problematic. ${ }^{108}$ Finally, the relative efficiency of this approach is also uncertain. While equalization may eliminate some inefficiencies by reducing community wealth as an incentive to individual mobility, it would not resolve congestion inefficiencies ${ }^{150}$ and might also introduce other ineffi-

155. This approach has received particular attention in the context of the school finance decisions. See notes 11 \& 12 supra.

156. It would not, however, alleviate the impact of differential input/output relat tionships. See note 154 supra. Morcover, to the extent that individuals suffer relative losses with respect to factors other than the varying costs of municipal services, sec pp. 118-19 supra, equalization of fiscal capacities does not provide full compensation. Of course, "compensation" in this context makes sense only if it is decided that the dis. tribution of wealth which accompanies a system of full mobility is the preferred distribution.

157. Standing alone, this mode of redistribution bears little dircet relationship to the fundamental interests isste discussed at pp. 108.11 supra. In the first place, despite equalization of fiscal capacities, a local political unit could provide its residents with nothing at all of a good or service which the courts had deemed fundamental. Consequently, equalization of fiscal capacities makes sense only if the fundamental interests concept is modified to require only that equal efforts (as meastired by percentage expenditures) should yield equal opportunity (as measured by dollar expenditures), the determination of effort levels being left entirely as a matter of individual choice. The equalization of fiscal capacities does not even comply with this watered-down standard, however, since it involves a transfer between communities, not between individuals. Within a political context, it guarantees only that some compromise level of effort will be reached; no individual is free to make his own atutonomous determination.

To a great extent, this latter difficulty disappears in the context of the Ticbout Hypothesis. That is, each local political unit sets up an effort level; through his locational choice, each individual makes an independent determination of the effort he wishes to expend. Consequently, cqualization of fiscal capacities bears a rational relationship to fundamental interests guarantees only insofar as it is coupled with unfettered mobility. And given inevitable restraints on mobility and limitations on the range of alternatives, this approach only crudely approximates the fundamental interests norm. While stuch imperfections may be of relatively minor significance in the context of cfficiency con. siderations, they may be of central importance in the context of fundamental interest guarantees.

158. Thus, fiscal capacity cqualizing may work to the disadvantage of the poor in those cases where they live in communities that enjoy an unustially large commercial and industrial tax base.

159. See pp. 106-08 supra. The cfficiency-generating characteristics of equalizing fiscal capacities were suggested by Buchanan \& Wagner, An Efficiency Basis for Federal Fiscal Equalization, in The ANalysis of Public Outrut 138 (J. Margolis cd. 1970). The position was disputed by Feldstein, Comment, in $i d$. at 159. "The avowedly "agnostic" tonc of 
ciencies by distorting prices for municipal services. ${ }^{100}$

The last alternative is simply to abolish exclusionary zoning. ${ }^{101}$ This approach obviously puts a high premium on individual mobility as opposed to community autonomy. ${ }^{102}$ Insofar as such enhanced mobility leads to a more even distribution of the population by income class with respect to local tax bases, this policy will also result in an equalization of fiscal capacities, though clearly the result will be slower and less complete than if done directly. A substantial redistributive effect in favor of the poor is also likely, in that low income individuals will be free to exploit all possible gains from relocation. ${ }^{103}$ Finally, the result is likely to eliminate any misallocation of resources resulting from excessively restrictive exclusionary zoning practices, while the policy itself will have no unwanted price effects. On the other hand, inefficiencies resulting from individual locational decisions made in the context of fiscal externalities ${ }^{164}$ would remain, and those preferring autonomy and homogeneity would be forced to bear substantial costs. ${ }^{165}$

\section{Conclusion}

In many respects, economic analysis of the distribution of municipal services is beset with uncertainties. Nevertheless, it provides a useful framework for examining judicial intervention. The crucial point is

Buchanan's more recent work, supra note 90 , at 40 , would seem to suggest that he, no longer views equalization of fiscal capacities as the efficient solution. Nerertheless, even under Buchanan's current formulation, equalization of fiscal capacities may generate certain efficiencies.

160. It artificially reduces the price of municipal services for some while artificially increasing it for others. The result may be a net under- or over-allocation of resources for the production of such services. See Musgrave, Approaches to A Fiseal Theory of Political Federalism, in PUblic Finasces: NeEd, Sources, ANd Uthizarion (National Bureau of Economic Research ed. 1961).

161. A policy of busing may be viewed as one variant of this approach. Insofar as it leads to a random distribution of school children by wealth and income. busing serves a substantial equalizing function.

162. Indeed, it could be argued that this policy would be over-inclusise, since it would inevitably cause communities to give up some values associated with restrictive zoning which are not directly related to the provision of municipal services. Sec p. 119 supra. On the other hand, a policy of fiscal capacity cqualizing would be under. inclusive, since it would leave some barriers to individual locational choice for which no compensation would be paid. See note 156 supra.

163. These gains would include private sector locational benefits, such as better employment, as well as such advantages as the ability to live in more aesthetic sur. roundings. They would also include gains related to exploitation of differential input/output ratios. See pp. 118-19 supra.

164. See pp. 106-08 supra.

165. The Pareto optimal solution would require creation of a system whereby such individuals could purchase their autonomy by paying off those they wished to exclude. See note 83 supra. 
that the distribution of municipal services is a process; it is not a static situation where changes wrought by the courts have only direct and obvious consequences. Despite imperfect knowledge, transactions costs, and impediments to mobility, individual locational decisions have sub. stantial efficiency generating properties which would be eliminated by a state-wide standard of per capita equality. The same is true, though with some qualifications, with respect to a mandated standard of intraunit per capita equality. Furthermore, individual locational responses to the latter measure would undoubtedly exacerbate the massive difficulties faced by central cities and their low income and minority residents. For the same reasons, the courts must also display greater care in distinguishing between wealth-related and race-related allo. cational disparities.

The locational process has a counterpart in the form of exclusionary zoning. Here, the courts are faced with a conflict between collective interests in local political autonomy and individual interests in unfettered residential mobility. The most direct judicial alternatives are to sanction or to prohibit exclusionary zoning. Whichever approach the courts take, there will be an effect on the distribution of income. In this context, the equalization of fiscal capacities is a halfway measure possessing uncertain consequences. It may provide partial compensation to some of those who have been injured by exclusionary zoning practices and other barriers to mobility, but such compensation will be imperfect and incomplete.

Finally, certain of the goods and services distributed by local government may be of such fundamental importance that all individuals have a right to them which should be protected by the courts. In such cases, however, protection should take the form of mandated distribution patterns independent of particular distributional processes. Thus, the courts may require some guaranteed adequate minimum; if so, deviations in availability above that minimum should be ig. nored. Alternatively, the courts could impose a standard of per capita equality; if so, then deviations from that standard, whether through the public or the private sector, should be prohibited. Once again, equalization of fiscal capacities is a halfway measure of dubious rationale and uncertain effect. 